\title{
Fibre-mediated physiological effects of raw and processed carrots in humans*
}

\author{
BY ELISABETH WISKER ${ }^{1}$, THOMAS F. SCHWEIZER ${ }^{2}$, MARTINA DANIEL ${ }^{1}$ \\ AND WALTER FELDHEIM \\ ${ }^{1}$ Christian-Albrechts University of Kiel, Institute of Human Nutrition and Food Science, \\ Düsternbrooker Weg 17, D-24105 Kiel, Germany \\ ${ }^{2}$ Nestlé Research Centre, Nestec Ltd, Vers-chez-les-Blanc, CH-1000 Lausanne 26, Switzerland
}

(Received 15 February 1993 - Revised 24 January 1994-Accepted 1 February 1994)

\begin{abstract}
Fibre-mediated physiological effects of raw and processed carrots were investigated in twenty-four young women under strict dietary control in two randomized crossover studies. For 3 weeks between 405 and $688 \mathrm{~g}$ of either raw frozen, blanched or canned carrots (first study), or raw or raw frozen carrots (second study) were consumed in addition to a low-fibre basal diet. Carrots provided $15 \mathrm{~g}$ dietary fibre (DF)/d. Total DF intake was 16.0 to $19.0 \mathrm{~g}$ (control periods) and 31 to $34 \mathrm{~g}$ (experimental periods). Faecal bulking effects of raw and processed carrots were similar (between 2.4 and $3.7 \mathrm{~g}$ additional stool $/ \mathrm{g}$ carrot fibre in the diet). Faecal excretion of dry matter, fibre, and protein also increased significantly during carrot consumption. Fermentability of carrot fibre constituents was high (91-94\%) and independent of processing, in spite of differences in the distribution of soluble and insoluble fibre and in the texture of raw and processed carrots. There was no effect of either type of carrot on serum total and high-densitylipoprotein-cholesterol or on faecal bile acid excretion.
\end{abstract}

Carrots: Fibre: Humans

Much of the plant food we consume is processed. Freezing, blanching, cooking and canning are procedures which are often applied to vegetables. Cooking especially is usually accompanied by tissue softening and changes in textural characteristics. Heating can affect the fibre content or modify the fibre distribution between water-soluble and insoluble fractions in several ways (Anderson \& Clydesdale, 1980; Nyman et al. 1987b; Lintas \& Cappeloni, 1988). Losses of soluble components such as sugars and minerals into the cooking water result in an apparent increase in fibre content. Solubilization of insoluble fibre increases the portion of soluble fibre. Degradation of polysaccharides into lowmolecular-weight fragments can have the same effect, but it can also decrease total fibre content, if oligosaccharides are formed which escape analysis by the normal methods for dietary fibre.

The chemical structure and the physicochemical properties of dietary fibre are both thought to determine their physiological effects. Therefore, it is often stated that modification of these properties may affect the action of fibre. Fibre sources containing high proportions of insoluble components like cereal brans and whole grain cereals have good faecal bulking capacities (Cummings, 1986), however, cooking of bran diminishes this

\footnotetext{
* Presented in part at the symposium Fibre 90: Chemical and Biological Aspects of Dietary Fibre, April 1990 in Norwich, England.
} 
effect (Wyman et al. 1976). More soluble types of fibre like those contained in fruits and vegetables or purified fibres like pectin are less effective in this respect. On the other hand, these fibres have a greater effect on blood lipids and on carbohydrate metabolism when they are consumed in sufficient amounts (Berger \& Venhaus, 1992; Truswell \& Beynen, 1992). Many actions of fibre are influenced by its fermentability in the large intestine. The effect on stool weight seems to be inversely related to the bacterial degradation of fibre (Stephen \& Cummings, 1980a). Soluble fibres are more easily fermented than insoluble fibres (Cummings, 1984). Heat treatment of cereals at low moisture, like popping and extrusion cooking, has been shown to increase fibre fermentability in the rat due to an increase of soluble components (Björck et al. 1984; Nyman et al. 1987a).

However, few human studies have actually addressed the effects of processing at high moisture levels such as those found in vegetables. The purpose of the present investigation was therefore to provide information on whether or not processing of a commonly eaten vegetable, i.e. carrots, affected the composition and solubility of fibre and thereby its physiological action in humans. Our main focus points in this study were colonic fermentation, bulking capacity of carrot fibre, and faecal excretion of fat, protein and bile acids. In addition, we hoped to resolve the question of whether or not carrots and carrot fibres exert cholesterol-lowering effects (Jenkins et al. 1979; Robertson et al. 1979).

\section{EXPERIMENTAL}

\section{Subjects}

A total of twenty-four healthy, free-living female subjects (22-29 years) took part in a series of balance experiments organized in two distinct studies. Informed written consent was obtained from all volunteers. The studies were approved by the Ethical Committee of the Medical Faculty of the University of Kiel.

\section{Study design}

All food consumed during the experiments was prepared in the institute kitchen and was weighed to the nearest gram. Extra food and energy-containing beverages were not permitted. The subjects had lunch together in the institute; foods for all other meals were prepacked for home consumption.

First study. The study comprised four experimental periods of $21 \mathrm{~d}$ each. The periods were separated from each other by at least 3 weeks to ensure that one dietary period had no residual effect on the next. During all periods the subjects consumed the same strictly controlled basal diet. This diet was supplemented either with a sugar jelly (low-fibre control diet), raw frozen, blanched frozen or canned carrots. The twelve subjects who took part in this study consumed each of the four diets in a randomized Latin square design.

Second study. Twelve subjects participated in the second study. The study comprised two experimental periods of $36 \mathrm{~d}$ each; the periods were separated from each other by 3 weeks. During the first $15 \mathrm{~d}$ of each period, all subjects consumed a low-fibre basal diet supplemented with a sugar jelly (low-fibre control diet). During the following $21 \mathrm{~d}$ the jelly was replaced by either raw or raw frozen carrots, subjects being assigned to these two treatments in a randomized crossover fashion.

\section{Diets}

The subjects had a controlled food intake that maintained their body weight in a range of $\pm 1 \mathrm{~kg}$ of their starting weight. Each subject's normal energy intake was calculated from a $7 \mathrm{~d}$ diet record by use of a food table (Deutsche Forschungsanstalt für Lebensmittelchemie, 
Table 1. Foods consumed daily during the low-fibre basal diet*

\begin{tabular}{llll}
\hline Food & $\begin{array}{c}\text { Intake } \\
(\mathrm{g} / \mathrm{d})\end{array}$ & Food & $\begin{array}{c}\text { Intake } \\
(\mathrm{g} / \mathrm{d})\end{array}$ \\
\hline Rye mixed bread & 200 & Yoghurt & 150 \\
Potatoes & 100 & Cheese & 75 \\
Cucumber or salad $\dagger$ & 150 & Soft cheese & 40 \\
Strawberries or orange $\dagger$ & 150 & Sausage & 40 \\
Meat balls & 75 & Honey/marmalade & 40 \\
Puddingt & 150 & Margarine & 20 \\
\hline
\end{tabular}

* Each subject consumed the same amount of these foods daily during each experimental period of the studies. Additional amounts of pudding, soft cheese, sausage, margarine and honey were eaten to adjust food intake to individual energy requirement.

$\dagger$ Foods were consumed in rotation.

¥ Pudding was prepared from milk, sugar, starch, eggs and vanilia.

1986). The low-fibre basal diet consisted of two $1 \mathrm{~d}$ menus of similar composition, which were fed in rotation throughout both studies. All subjects consumed the same amount of fibre-containing foods, whereas fibre-free foods corresponded to individual energy requirements. The foods consumed during the basal diet are given in Table 1.

\section{Carrots}

Carrots (Daucus carota sp. sativus) harvested in 1988 and in 1990 were used in the studies.

During the first study, raw carrots (harvested in 1988) from the same batch were washed, steam-peeled, trimmed, cut into pieces $(10 \times 10 \times 10 \mathrm{~mm})$ and rinsed. The prepared vegetables were either frozen and packaged (raw frozen carrots), or water blanched at $98-100^{\circ}$ for $2 \mathrm{~min}$, cooled after blanching at $10^{\circ}$ for $2 \mathrm{~min}$, frozen and packaged (blanched frozen carrots), or canned at $120^{\circ}$ for $20 \mathrm{~min}$ (canned carrots). Carrots were prepared in an amount sufficient for the consumption during all study periods. Thus it was ensured that each type of carrots had a constant composition throughout the study.

During the second study, raw and raw frozen carrots were obtained from one batch of carrots harvested in 1990. Raw frozen carrots were prepared as described above. Raw carrots were stored at $2^{\circ}$ until they were consumed. They were prepared by washing, peeling by hand and coarse scraping.

Daily intakes of raw and processed carrots were calculated to provide $15 \mathrm{~g}$ total dietary fibre, as analysed by the method of Prosky et al. (1985). Table 2 shows the intake of carrots, of total dietary fibre and sugar derived from carrots and the intake of sugar from jelly. Table 3 gives the intake of energy and nutrients during the experimental periods.

\section{Blood collection}

During the first study, at days 2 and 21, in ten subjects venous blood samples were obtained from a superficial arm vein by venepuncture after $12 \mathrm{~h}$ fasting. During the second study, blood was drawn in eleven subjects at days 2,15 and 36.

\section{Balance technique}

In the first study, balances were performed during the last week of each experimental period. During the second study, balances were performed from days 9 to 15 (low-fibre control diet) and from days 30 to 36 of each experimental period. Duplicates of all food 
Table 2. Daily intake $(\mathrm{g} / \mathrm{d})$ of carrots, carrot fibre and sugar from carrots and jelly*

\begin{tabular}{|c|c|c|c|c|}
\hline & \multicolumn{2}{|c|}{ Carrots } & \multicolumn{2}{|c|}{ Sugar from: } \\
\hline & Amount & Dietary fibre & Carrots $\dagger$ & Jellył \\
\hline \multicolumn{5}{|c|}{$\begin{array}{l}\text { Carrots harvested in } 1988 \\
\text { (first study) }\end{array}$} \\
\hline Control & - & - & - & $32 \cdot 0$ \\
\hline Raw frozen & 575 & 15.0 & 32.0 & - \\
\hline Blanched frozen & 508 & 15.0 & $21 \cdot 4$ & $10 \cdot 6$ \\
\hline Canned & 688 & $15 \cdot 0$ & $15 \cdot 4$ & 16.6 \\
\hline \multicolumn{5}{|c|}{$\begin{array}{l}\text { Carrots harvested in } 1990 \\
\text { (second study) }\end{array}$} \\
\hline Control & - & - & - & $32 \cdot 0$ \\
\hline Raw & 405 & 15.0 & 32.8 & - \\
\hline Raw frozen & 469 & $15 \cdot 0$ & 31.9 & - \\
\hline
\end{tabular}

consumed were weighed, homogenized, and frozen at $-25^{\circ}$ until freeze-dried. Faeces were collected quantitatively and frozen at $-25^{\circ}$. Acid brilliant green (E 142, provided by H. Schulz, Dragoco, Holzminden, Germany) was given as a faecal marker at the beginning and the end of each collection period. After each balance period faeces were thawed, pooled together, and homogenized before freeze-drying a portion. Faeces collected during the lowfibre control diets (days 9 to 15) in the two experimental periods of the second study were pooled together and one sample for each subject was freeze-dried.

\section{Analytical methods}

Freeze-dried samples of food and faeces were milled through a $0.5 \mathrm{~mm}$ mesh screen. Total dietary fibre in the diet was determined gravimetrically by the method of Prosky et al. (1985) using the buffers as described by Prosky et al. (1988). Insoluble dietary fibre was measured according to Prosky et al. (1988). Neutral non-starch polysaccharides (NSP) in foods and faeces were determined by GLC as alditol acetates by the method C of Theander \& Westerlund (1986) using 1-methylimidazole as a catalyst for the derivatization of NSP monomers. Corrections for hydrolytic losses and detector response were made by performing the analyses with known sugar standards. Uronic acids were measured in the acidic hydrolysate according to the method of Englyst \& Cummings (1984). Total NSP was calculated as the sum of neutral sugars and uronic acids and expressed as polysaccharides (weight of monomers $\times 0.9$ ). $\mathrm{N}$ was analysed by a microKjeldahl method; protein was calculated as $N \times 6 \cdot 25$. Crude fat was determined after acid hydrolysis by extraction with petroleum ether $\left(40-60^{\circ}\right)$. Ash was determined in a muffle furnace at $550^{\circ}$. Dry matter of diets and faeces was obtained by drying the freeze-dried samples to constant weight at $105^{\circ}$ (Arbeitsgemeinschaft Getreideforschung, 1978). Starch was measured as described by Bach Knudsen et al. (1987). Sugars were analysed after water extraction using enzyme test kits (Boehringer Mannheim GmbH, Mannheim, Germany). Serum total cholesterol was determined enzymically by the CHOD-Iodide method (Merckotest 14350; Merck, Darmstadt, Germany). High-density-lipoprotein (HDL)-cholesterol was measured by precipitating all other cholesterol fractions with heparin and $\mathrm{Mg}$ (Fällungsreagenz 15007; Merck) (Eckel et al. 1977) leaving a supernatant that was assayed for cholesterol by use of 


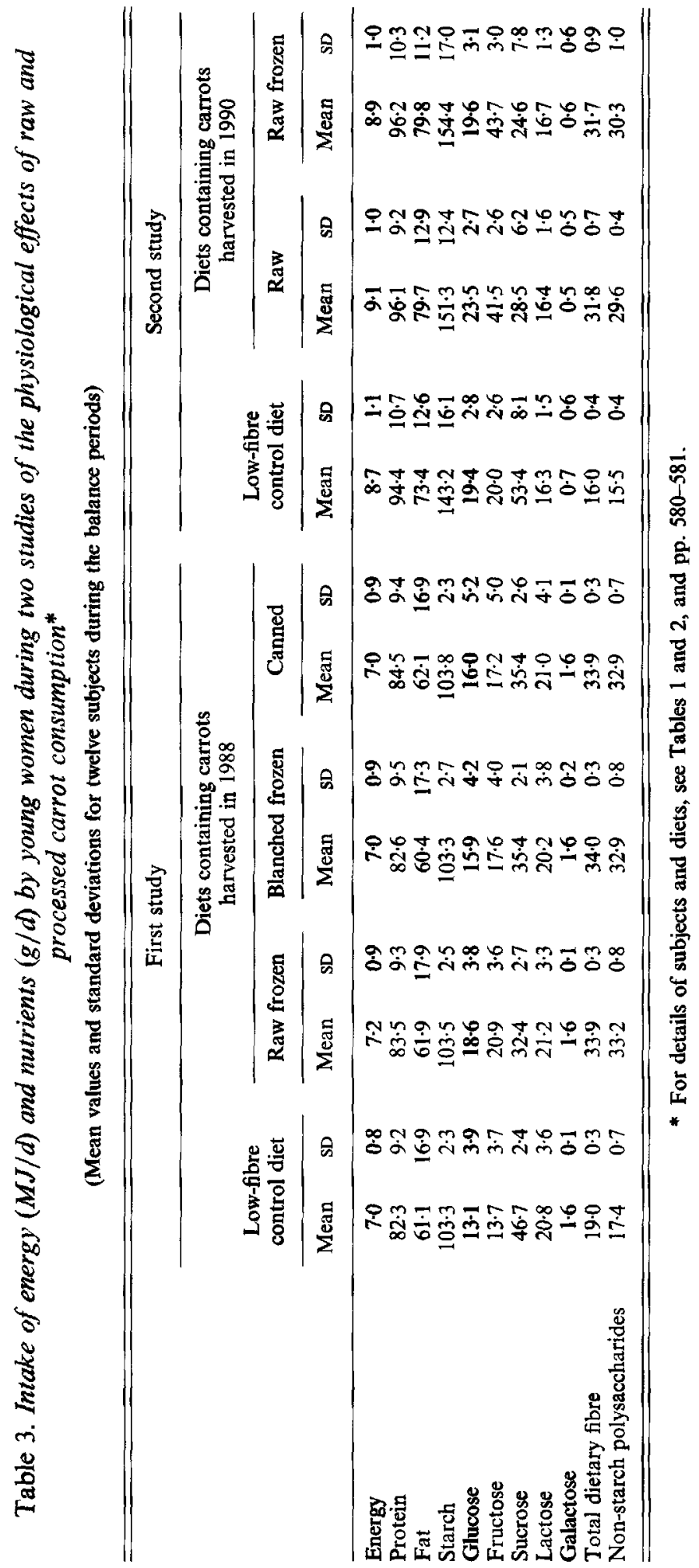


a test kit (Merckotest 14350). Accuracy of total cholesterol and HDL-cholesterol determinations were ensured through measurement of a standard serum (Kontrollogen LP; Behringwerke, Marburg, Germany). Faecal bile acids were measured by GLC after extraction from powdered dry faeces, saponification, separation from neutral steroids and derivatization as described by Schweizer et al. (1983).

\section{Calculations}

Soluble fibre was calculated as the difference between total and insoluble fibre. Fermentability of NSP constituents of the diets was calculated as the difference between dietary intake and faecal excretion, expressed as a percentage of intake.

During the second study, intake, faecal excretion and fermentation of NSP derived from carrots were also calculated. Intake and faecal excretion of carrot NSP were calculated as the difference between carrot-containing diets and the corresponding low-fibre control diets. Fermentation of carrot NSP was calculated as the difference between estimated dietary intake and faecal excretion, expressed as a percentage of intake. Faecal output due to carrots during the second study was calculated as the difference between carrotcontaining diets and the corresponding low-fibre control diets.

\section{Statistical analysis}

The effects of processing on the composition of the carrots consumed during the first and second studies respectively, and the effects of the harvest year on the composition of raw frozen carrots were analysed by one-way analysis of variance. Linear contrasts were used to compare treatment means.

The results of the studies were treated statistically by analysis of variance in which subject, period and diet effects were evaluated. Results obtained with diets containing raw frozen carrots harvested in 1988 and in 1990 were compared by one-way analysis of variance in which the effect of the harvest year was determined. Where significant differences between diets were established, differences were tested by linear contrasts. Linear contrasts were established by Student's $t$-test with comparison-wise error rates (General linear models procedure (GLM), SAS Institute, Heidelberg, Germany). All tests were considered significant at the $5 \%$ level $(P<0.05)$.

\section{RESULTS}

\section{Composition of carrots}

The total dietary fibre and NSP content of the carrots, the percentage of soluble and insoluble fibre and the NSP monomers are given in Table 4.

Heat treatment, i.e. blanching and canning, increased the fibre content in carrot dry matter compared with raw frozen carrots due to losses in non-fibre material, mainly sugars. On a fresh weight basis the fibre values were higher in blanched and lower in canned than in raw frozen carrots. Blanching and canning also increased the percentage of soluble fibre compared with the raw frozen carrots. The raw frozen carrots from the 1990 harvest contained more dietary fibre than those harvested in 1988, calculated on a fresh weight basis, whereas the values in the dry materials were the same. Freezing reduced the dietary fibre content compared with the raw carrots when the values were calculated on a fresh weight basis, but in the dry material there was no difference. The percentage of soluble fibre was the same for both raw and raw frozen carrots and was higher compared with the value of the raw frozen carrots from the 1988 harvest. The main dietary fibre constituents in 
FIBRE IN RAW AND PROCESSED CARROTS

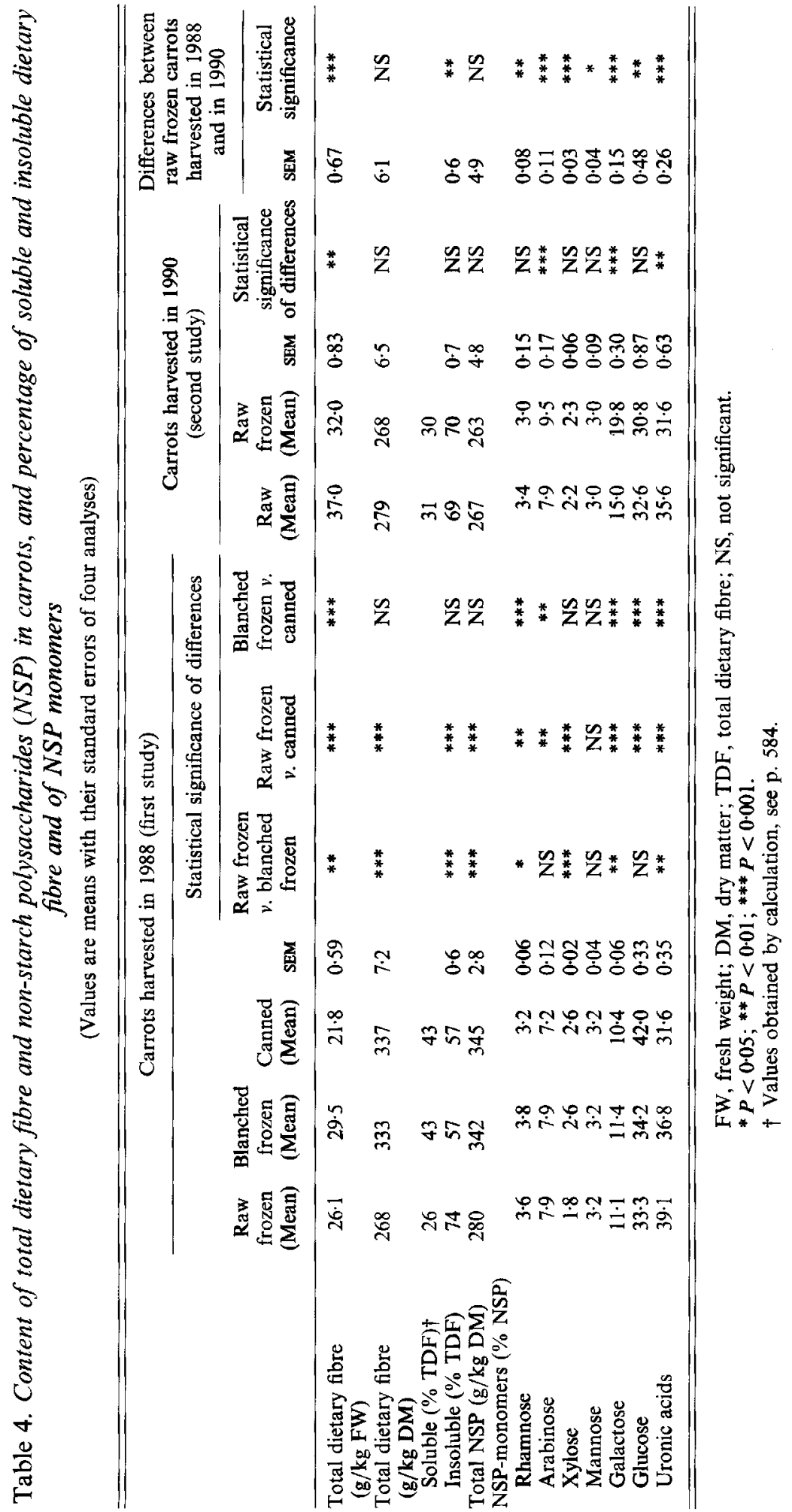


carrots were uronic acids and glucose, followed by galactose and arabinose. In comparison to the raw frozen carrots, blanching had no effect on the percentage of glucose, but decreased uronic acids, whereas canning caused a decrease in uronic acids and an increase in glucose. Compared with the raw carrots, freezing increased arabinose and galactose and decreased uronic acids.

\section{Effect of carrots on faecal excretion}

The effect of the consumption of carrots harvested in 1988 on important faecal variables is shown in Table 5. The consumption of carrots caused an increase in faecal wet and dry weight compared with the values on the control diets. For each gram of additional fibre, wet weight increased between 2.4 and $3.7 \mathrm{~g}$, mean dry weight by $0.4 \mathrm{~g}$. The fibre from the various carrots led also to significantly elevated losses of water, NSP, N and ash, whereas fat excretion was not affected. An influence of processing of carrots could only be observed in the case of stool water which was higher during the consumption of raw frozen and blanched frozen carrots compared with canned carrots. The mean daily faecal bile acid excretion and the high extent of conversion of primary to secondary bile acids were similar in all periods of the first study.

The results of the second study (carrots harvested in 1990) are shown in Table 6. Faecal output increased due to carrot consumption, but no differences in the effects of raw and raw frozen carrots could be observed.

\section{Fermentation of carrot NSP}

Table 7 shows the intake, faecal excretion and fermentation of NSP monomers during the first study. Although the diets containing raw frozen, blanched or canned carrots from the 1988 harvest provided higher amounts of NSP monomers than the control diet there was no, or only a small, increase in faecal excretion of the monosaccharides, even when the differences from the control diet were significant. The additional fibre constituents were extensively degraded, leading to higher values for the fermentation of NSP monomers during the carrot-containing diets than during the control diet. Compared with the control, total NSP intake increased by $15.8,15.5$ and $15.5 \mathrm{~g} / \mathrm{d}$ when the raw frozen, blanched, and canned carrots respectively, were consumed. The corresponding NSP losses increased on average by $1.3,1.4$ and $0.9 \mathrm{~g} / \mathrm{d}$ respectively. From these values it was estimated that a mean of 92,91 and $94 \%$ of fibre in the raw frozen, blanched, and canned carrots from the 1988 harvest respectively, was broken down. No significant effect of processing of carrots on the fermentation of NSP could be observed.

Table 8 gives the intake, faecal excretion and fermentation of NSP during the second study. There were no differences in faecal losses and digestibilities of NSP monomers between the two carrot-containing diets with the exception of galactose fermentation. The additional fibre constituents provided by raw or raw frozen carrots from the 1990 harvest were extensively fermented, independent of whether the fibre originated from raw or raw frozen carrots. The most resistant NSP constituents were glucose-containing polymers.

Table 9 shows a comparison of the effects of the diets containing raw frozen carrots from the two harvest years. There were few differences between the effects of the two diets.

\section{Effects on serum cholesterol}

Table 10 gives the concentrations of serum total cholesterol and of HDL-cholesterol during the first study. Both serum total cholesterol and HDL-cholesterol decreased within each experimental period, independent of the diet. However, there were no differences in the 


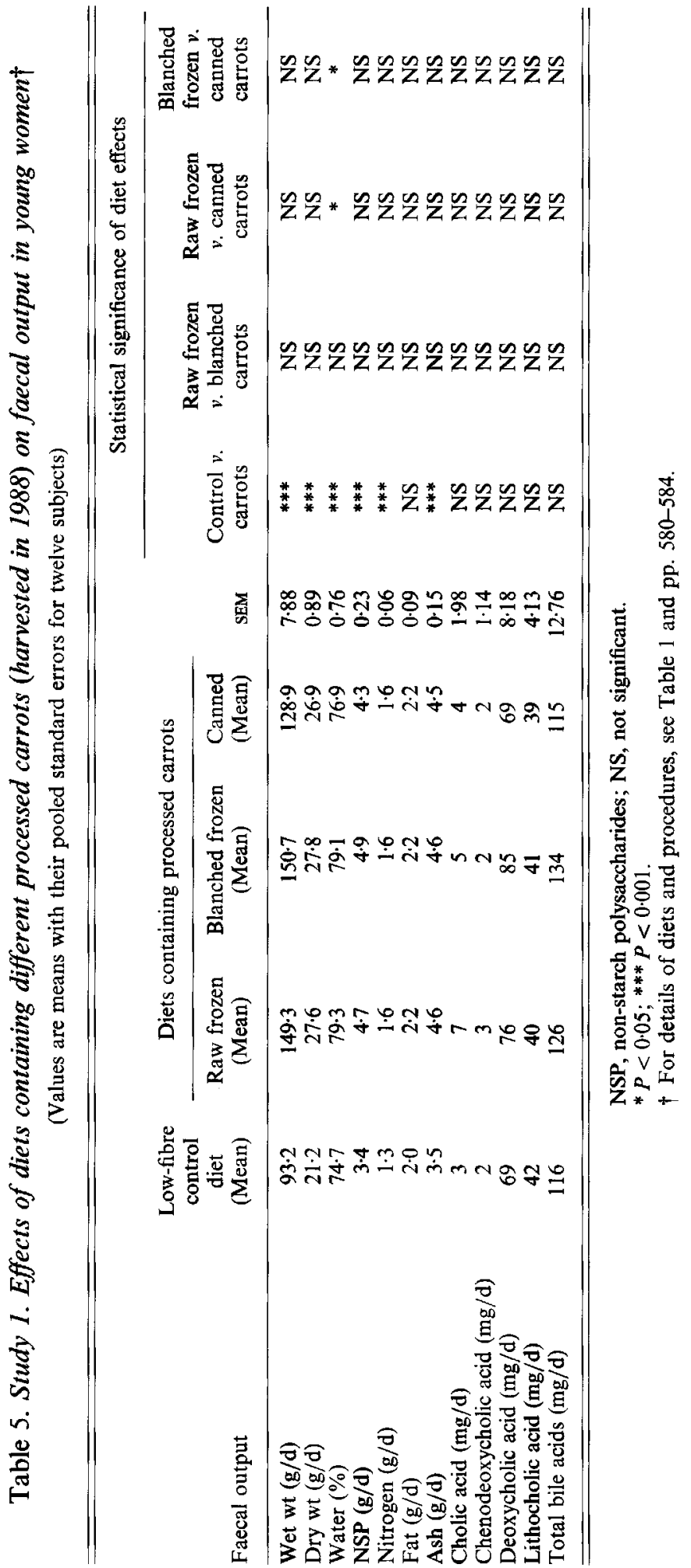




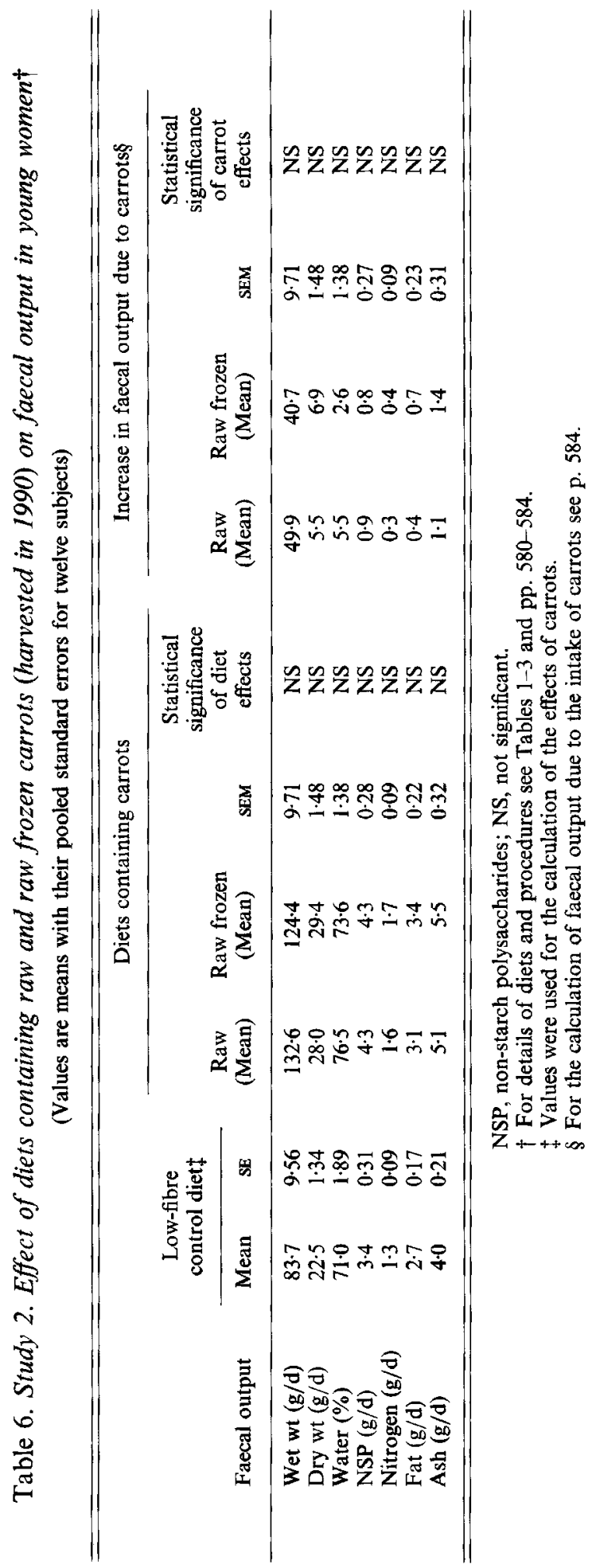




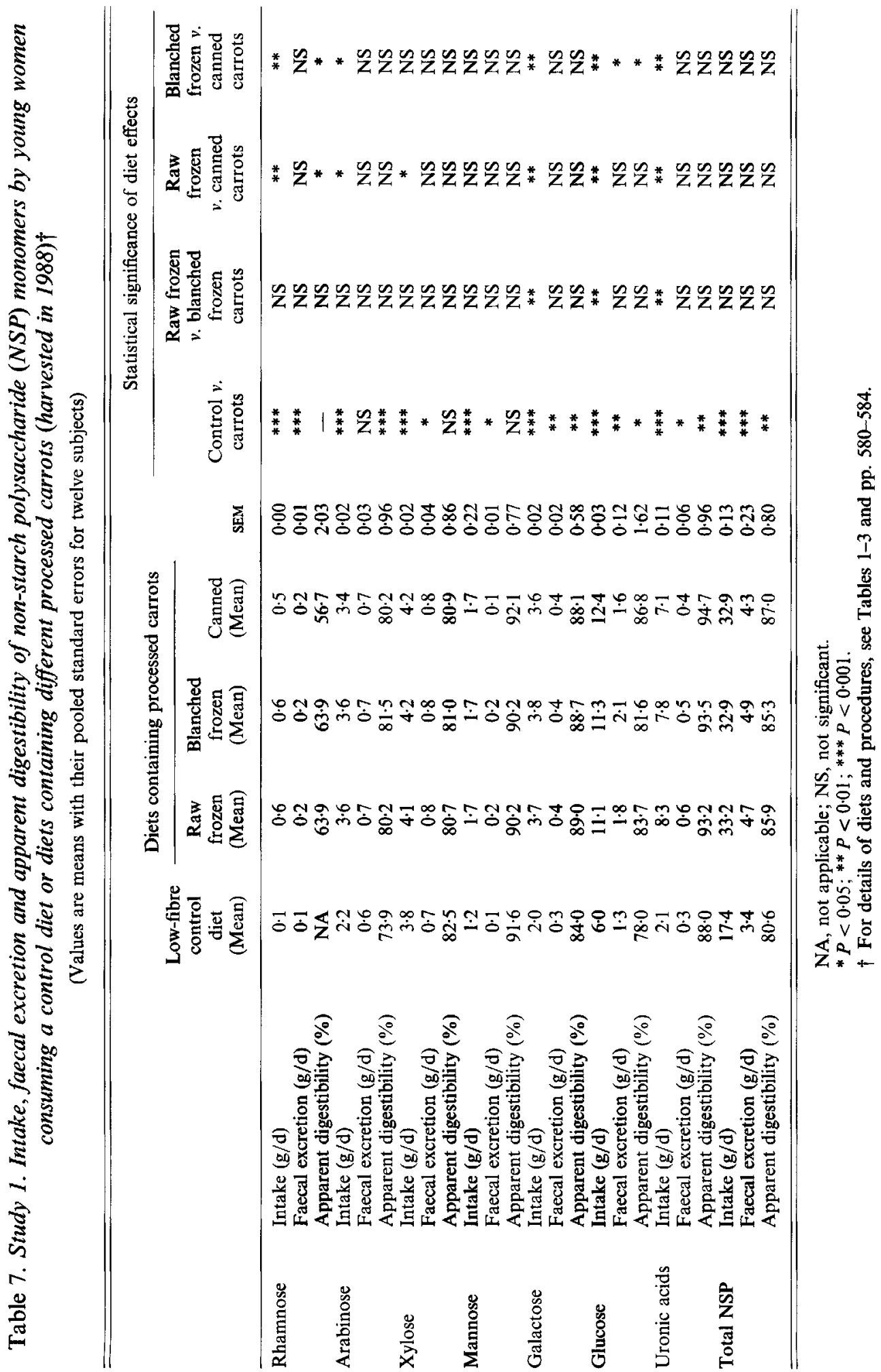


E. WISKER AND OTHERS

(5)

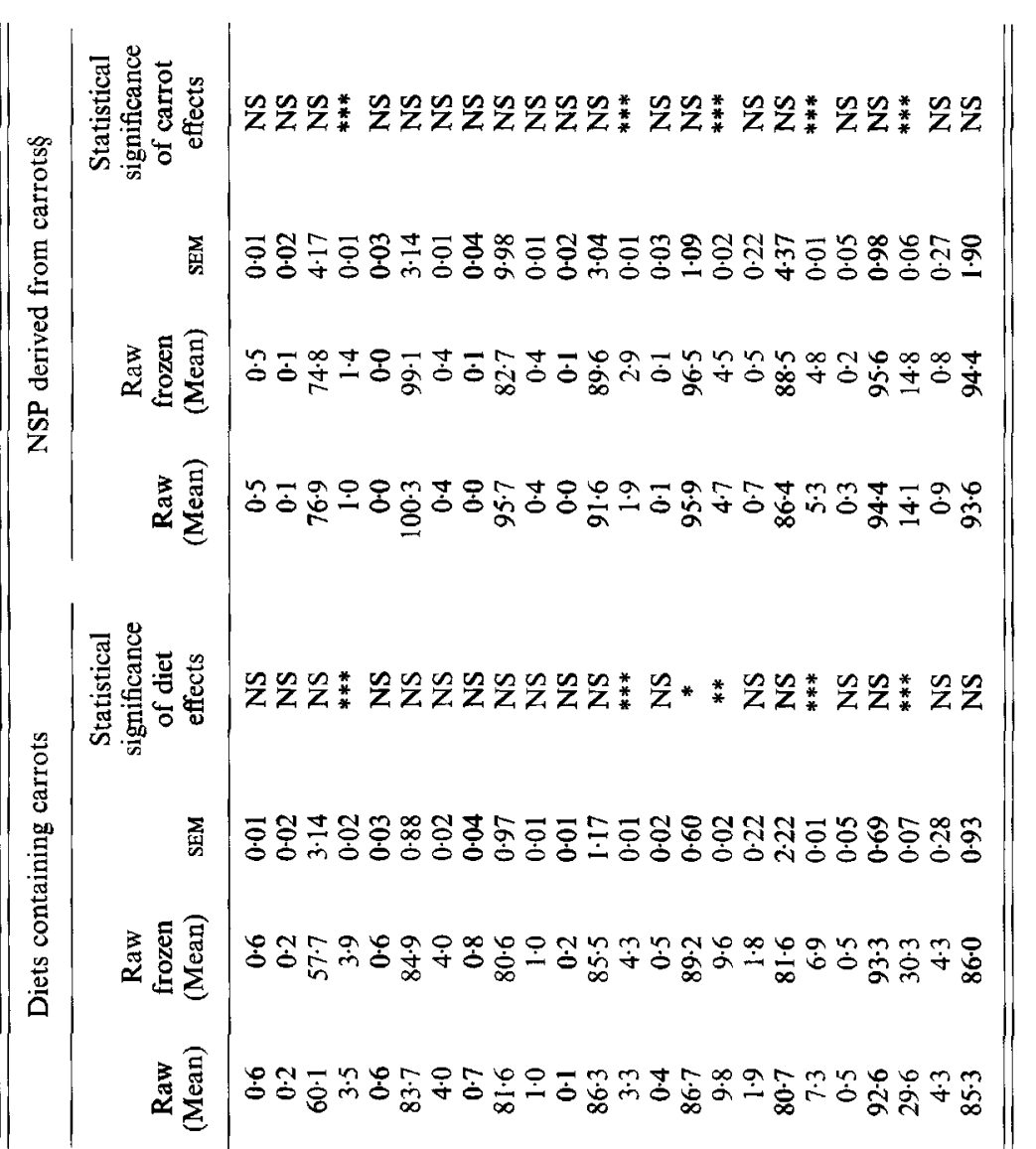

5 乙

\section{कृ}

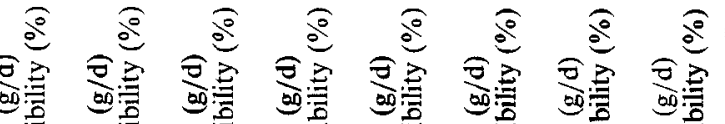
要

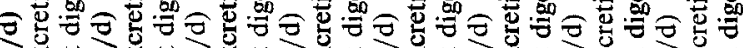
क्री

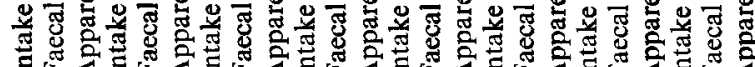

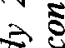




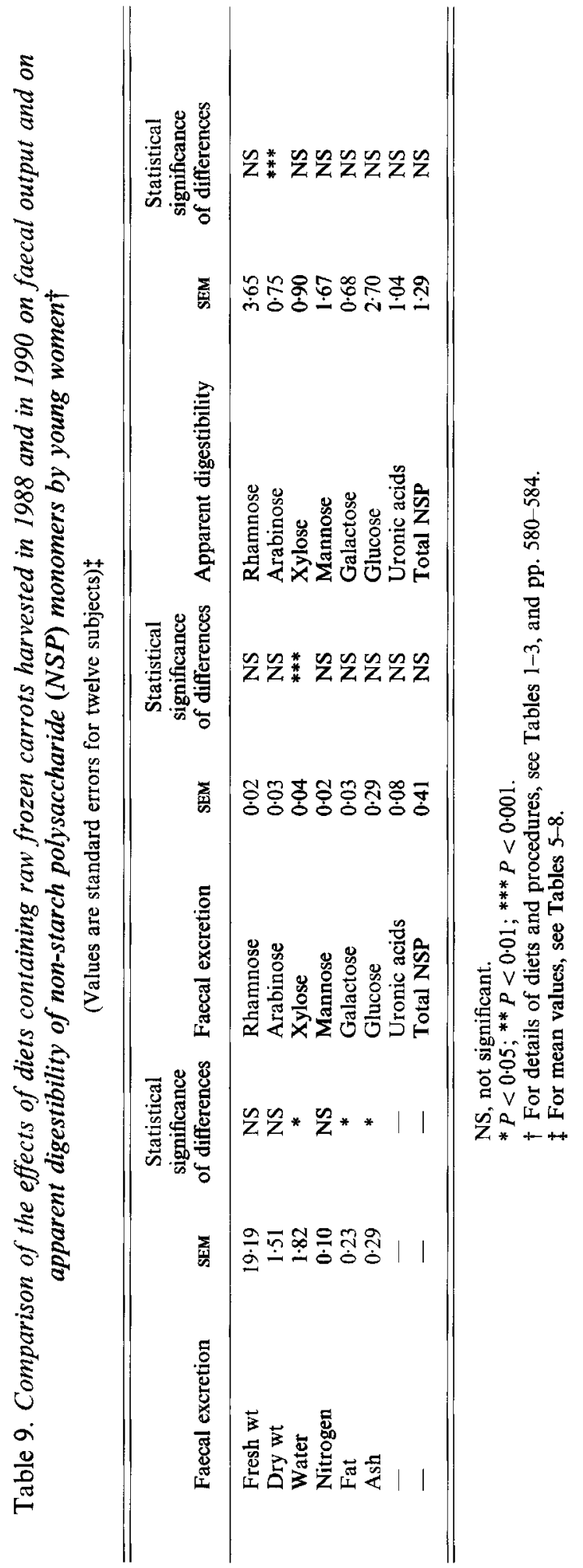




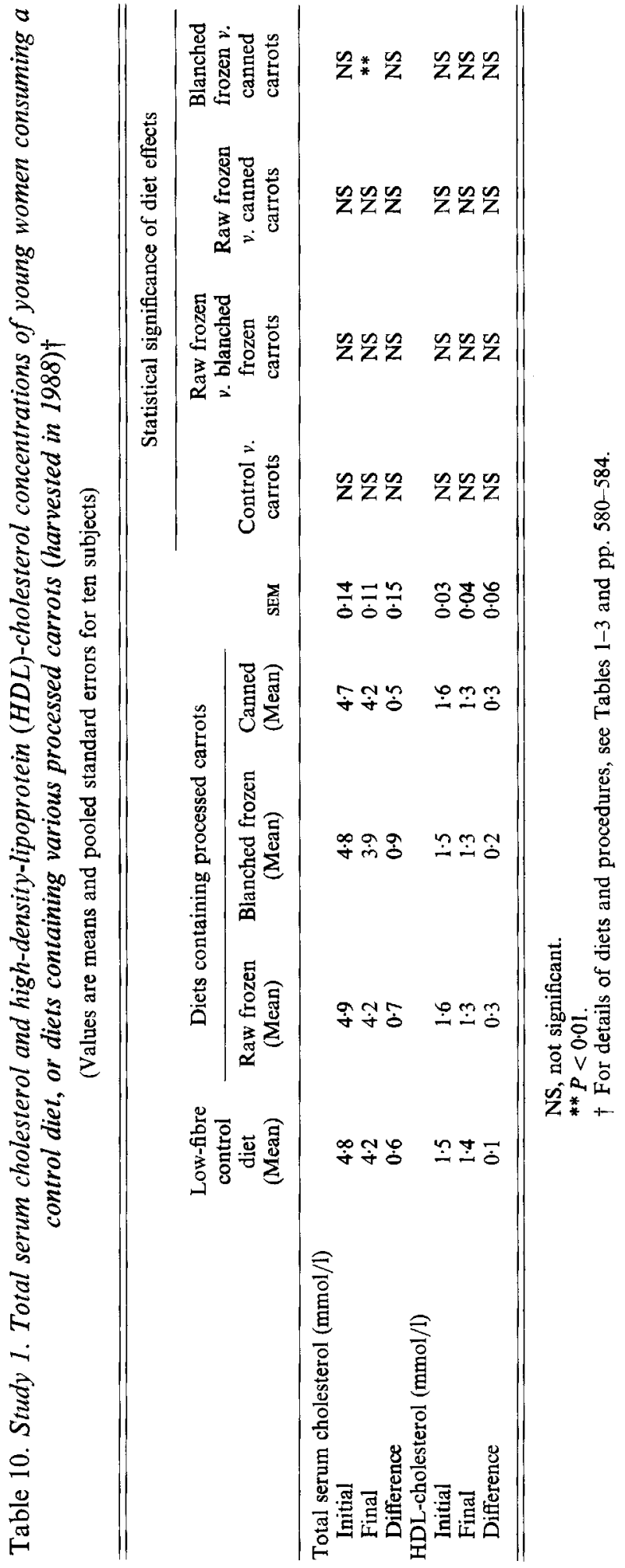




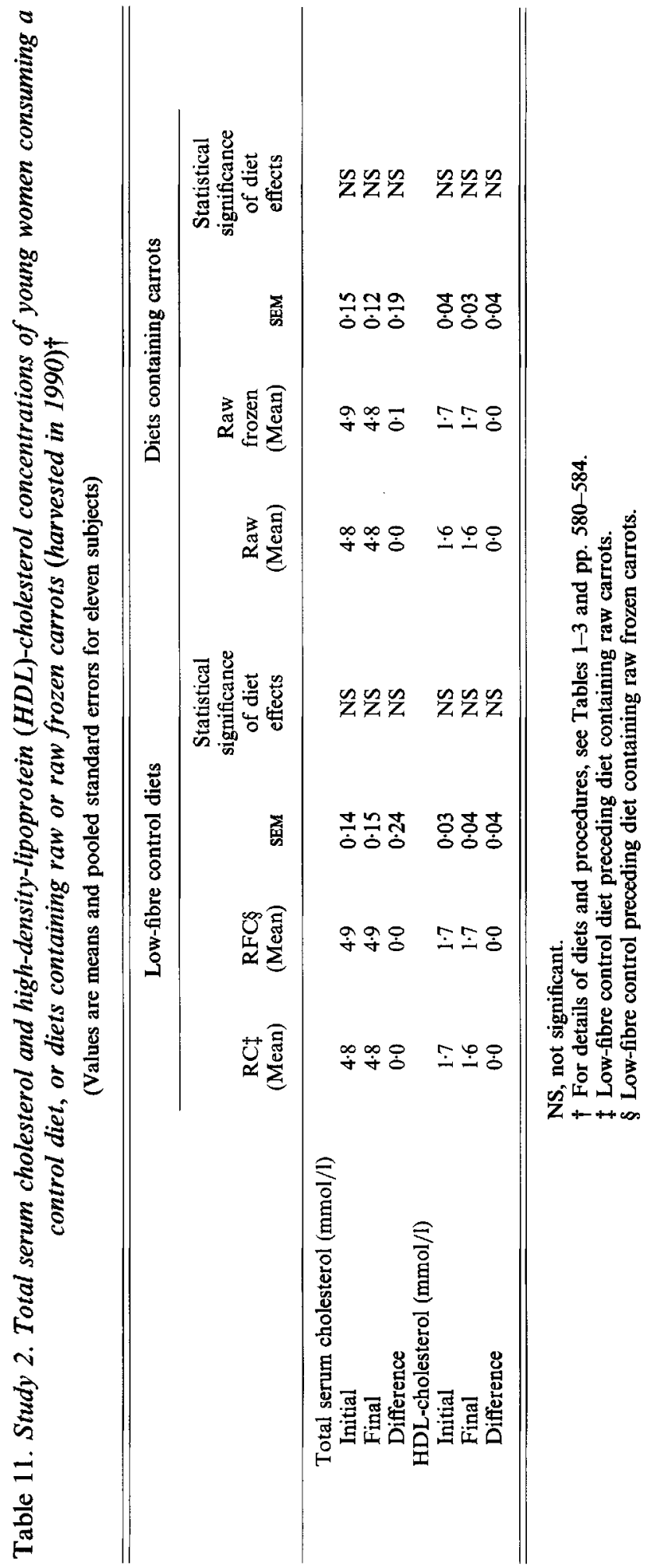


decreases between the different experimental diets. Table 11 shows the cholesterol values measured during the second study. There were no changes in serum total cholesterol and in HDL-cholesterol during the low-fibre control diets or during the carrot-containing diets.

\section{DISCUSSION}

In this work we investigated whether or not processing of carrots had an influence on various fibre-mediated physiological effects of carrots. For practical reasons (length and number of study periods, keeping quality of raw carrots) the raw carrots in the first study were frozen. The second study was conducted mainly in order to see whether such raw frozen carrots would indeed closely match raw carrots in their physiological effects. We also hoped to reveal any differences in raw frozen carrots which could be attributed to different harvest years.

\section{Dietary fibre content in carrots and structure of cell walls}

Because processing changed the total dietary fibre content in carrots, different amounts of carrots had to be consumed to achieve equal intakes of fibre. Similarly, as shown in other studies (Anderson \& Clydesdale, 1980; Nyman et al. 1987 b; Lintas \& Cappeloni, 1988), heat treatment affected the chemical composition and the physical structure of the carrot fibre. Both blanching and canning increased the percentage of soluble fibre, probably due to cleavage of glycosidic linkages in polysaccharide chains producing smaller compounds. Freezing had no effect in this respect. These findings corroborate the microscopic examination of the carrot cell walls (C. Schlienger, personal communication). The cell walls of the raw carrots were dense with a very clear middle lamella and cellulose microfibrils adhered to each other. Only very few lesions could be seen. The structure of the raw frozen carrots was similar to that of the raw carrots with some more lesions but no definite breaks in the cell walls. Blanching caused the carrot cell wall to swell. Probably due to the solubilization of pectin, walls split at the level of the middle lamella and intercellular spaces. A dissociation of the walls could be observed, but they did not break up completely. The canned carrots suffered the most important cell lesions. Not only the pectin but also the hemicellulose bridges had been denaturated. The cellulose microfibril group dissociated and swelled. Due to the swelling of the matrix the tissues lost their rigidity. Thus, the canned carrots were much softer compared with blanched and frozen carrots, and especially with raw carrots which were very hard.

\section{Effect of processing of carrot fibre on fermentation and faecal output}

Several physiological effects of dietary fibre are related to its degradation in the large intestine. The fermentative breakdown of dietary fibre polysaccharides may be of importance because of its impact on energy supply not only to the colonic mucosa (Roediger, 1980) but also for the body as a whole (McNeill, 1984). There are also hypotheses that short-chain fatty acids resulting from the fermentation may affect liver metabolism (Chen et al. 1984) and may play a role in the protection against colonic carcinogenesis due to their contribution to lowering colonic $\mathrm{pH}$ (Jacobs, 1990). Fibre fermentation was found to be inversely related to its stool bulking capacity (Stephen \& Cummings, 1980a).

In our measurements of faecal saccharides we could not distinguish between unfermented dietary saccharides and those potentially derived from bacterial or endogenous origin. It is difficult to study the basal saccharide excretion on a fibre-free diet in humans as can be done in rats (Nyman et al. 1991). However, studies in man and rats provide evidence that 
saccharides of mucins and mucopolysaccharides produced by the host are utilized by the gut microflora (Salyers \& McCarthy, 1989). Animal experiments indicate that the contribution of bacteria to faecal NSP may be only small (Nyman \& Asp, 1985). In an investigation of the carbohydrate content of faecal bacteria of pigs it was found that NSP accounted for only $4.3 \%$ of bacterial dry matter. Glucose $(2 \cdot 36 \%)$, galactose $(0 \cdot 96 \%)$, rhamnose $(0.71 \%)$ and uronic acids $(0.3 \%)$ were the main components (Longland \& Low, 1990). In human faeces, up to $55 \%$ of faecal dry matter can consist of bacteria (Stephen \& Cummings, $1980 \mathrm{~b}$ ). If these bacteria contained similar amounts of NSP to those found in the microflora of pigs (Longland \& Low, 1990), in our study they could have contributed a maximum of $0.3,0.1,0.1$ and $0.05 \mathrm{~g}$ of glucose, galactose, rhamnose, and uronic acids respectively to the daily faecal losses of these saccharides, with only negligible differences between the single experimental periods. Therefore we can safely assume that measurements of apparent digestibility of fibre as performed in this study provide relevant information about true fibre fermentation.

The potential susceptibility of dietary fibre to fermentation by bacterial enzymes seems to be dependent on its solubility. Soluble components are more easily degraded than insoluble ones (Cummings, 1984). Provided that the additional consumption of carrot fibre had no effect on the digestibility of fibre in the basal diet (Key \& Mathers, 1990), carrotfibre fermentation may be estimated from differences in the amount of fibre intake and excretion between the carrot-containing diets and the corresponding control diets. According to this calculation, fibres from the different carrots were fermented equally and rather completely (91-94\%). The higher proportion of insoluble fibre components in the raw and raw frozen carrots compared with the blanched and canned carrots, and also the more intact cell walls which could be observed microscopically, did not protect them from extensive degradation. The most resistant saccharides were glucose, representing mainly cellulose, and rhamnose, representing the resistant core regions of the carrot pectins.

When similarly processed carrots as used in our studies were fed to rats, fibre fermentability differed from one harvest to the other (Nyman et al. 1991). During one year, blanched carrots were fermented only to $53 \%$ compared with raw frozen and cooked carrots which were degraded to 74 and $84 \%$ respectively. However, carrots from another year were fermented to a higher degree (83-91\%) and were unaffected by processing, as was the case in the present study. In contrast to the studies in rats, no influence of the harvest year on the fermentation of carrot fibre could be observed in our human study involving different harvest years. At such a high fermentation efficiency subtle cell wall differences due to harvest year or processing are indeed not likely to be important. However, when the overall fermentation rates measured in humans are compared with those in rats, it appears that fermentation was slightly more complete in humans.

Faecal bulking capacity of carrot fibre was comparable with the effects of other vegetables (Wisker \& Feldheim, 1990) and of finely ground cereal brans (Wisker et al. 1986, 1992), although the carrot fibre was fermented to a higher degree. The increase in stool weight was due to an elevated output both of dry matter and of water. The percentage of faecal water increased with the raw frozen and blanched carrots from the 1988 harvest and with the raw carrots harvested in 1990 . This was probably caused by reduced transit times, because under these conditions there might have been less time for water reabsorption (Cummings, 1986). However, transit times were not measured in this study. The higher excretion of faecal $\mathbf{N}$ during the consumption of the different carrots may reflect an increase in microbial mass due to the fermentation of the carrot fibre (Stephen \& Cummings, $1980 b)$.

There were no differences in the faecal bulking effects between various processed carrots of the same harvest and also no differences between carrots from different harvests, 
although there were changes in the chemical composition and in the solubility characteristics of the carrot fibre. This is consistent with the equal fermentability of all carrots found in this human study. In the study with rats (Nyman et al. 1991) the blanched carrots with the lowest fermentability had a greater effect on faecal wet and dry weight compared with raw frozen and cooked carrots. However, this effect could not be repeated when carrots from a different harvest year were studied. Faecal bulking and fermentability were therefore closely related in both humans and in the rat model.

\section{Serum cholesterol and faecal bile acids}

Highly fermentable isolated fibre sources like pectin have been shown to reduce serum cholesterol levels (Stasse-Wolthuis et al. 1980). A few studies have also reported such an effect after consumption of different vegetables (Gormley et al. 1977, 1979) and carrots (Robertson et al. 1979). The mechanism by which dietary fibre affects the metabolism of serum lipids is not fully understood. A decreased absorption of bile acids because of binding to dietary fibre in the intestinal lumen and the inhibition of hepatic cholesterol synthesis by the products of fermentation, the short-chain fatty acids, are discussed as possible mechanisms (Kritchevsky \& Story, 1986).

During the first study the consumption of the experimental diets resulted in a reduction in the concentration of both serum total and HDL-cholesterol. However, because an equal cholesterol lowering could also be observed during the control diet, it could not be attributed to fibre present in the different carrots. Rather the decrease in cholesterol may have been due to differences in the fat content of these subjects' normal diets and the experimental diets consumed in the study. The experimental diets contained less energy in the form of fat $(32 \%)$ compared with average German diets $(42 \%$; Deutsche Gesellschaft für Ernährung, 1988). Changes in the amount of dietary fat can affect serum total cholesterol (Stasse-Wolthuis et al. 1979). This interpretation is supported by the results of the second study, when neither the control diet nor the diets containing raw or raw frozen carrots had any effect on serum total and HDL-cholesterol. However, in this second study the low-fibre basal diet, which preceded the carrot-containing diets in order to avoid differences other than carrots between pre-study diets and experimental diets, did not exert any influence on serum cholesterol.

As our subjects were young women, cholesterol values may have been influenced by the menstrual cycle. However, the fluctuations in HDL- and total cholesterol during a normal menstrual cycle do not apparently show a clear pattern. No changes and a cyclical decrease in cholesterol values have both been reported (Adlercreutz \& Tallqvist, 1959; Demacker et al. 1982). In users of oral contraceptives a cyclical decrease in HDL- and total cholesterol was observed (Demacker et al. 1982). Thus, the time of blood sampling during the cycle may be important. During our studies blood samples were taken independently of the menstrual cycle of the subjects. However, it is unlikely that there was a systematic effect of menstrual cycle, because the experimental periods lasted 3 weeks each and were separated from each other by 3 weeks. A decrease of HDL-cholesterol together with total serum cholesterol was also reported when beans (Anderson et al. 1990) or various dietary fibre sources (Stasse-Wolthuis et al. 1979; Kesäniemi et al. 1990) were consumed by male subjects (Anderson et al. 1990; Kesäniemi et al. 1990) or by subjects of both sexes (StasseWolthuis et al. 1979).

The decrease in serum cholesterol during the first study was not connected with increases in faecal bile acid excretion. Faecal bile acids were more dilute after carrots than after the control diet, but the interindividual variation was considerable. Compared with other studies (Schweizer et al. 1983) bile acid losses were rather small, probably due to the low consumption of fat with these diets. 
Isolated pectin has been shown to decrease serum cholesterol in several studies. The smallest amount showing a significant effect was a dose of $9 \mathrm{~g}$ pectin/d (Stasse-Wolthuis et al. 1980). Pectic substances, measured as uronic acids, contribute about one third to carrot fibre. The carrots consumed in our studies provided daily between 5 and $6 \mathrm{~g}$ uronic acids, an amount which was probably too small for a cholesterol-lowering effect. In addition, native pectic substances present in cell walls differ from isolated pectin in respect to molecular weight and number of side chains and therefore may exert different physiological effects than isolated pectin.

Thus, our results differ from those of Robertson et al. (1979) who reported a significant lowering of slightly elevated serum total cholesterol when $200 \mathrm{~g}$ raw carrots corresponding to $6 \mathrm{~g}$ carrot fibre per day were consumed over 3 weeks in addition to a freely chosen diet. This cholesterol-lowering effect was also accompanied by an increase in faecal bile acid excretion. More in agreement with our findings, the addition of isolated fibres from carrots, cabbage or apples to a controlled diet had no effect on normal serum total cholesterol levels, but the carrot fibre caused a decrease of HDL-cholesterol, which could not be explained (Jenkins et al. 1979).

\section{Conclusions}

Our investigations in humans have shown that dietary fibres in carrots are highly fermentable and yet have good stool-bulking ability, comparable to finely milled cereal brans. In spite of appreciable effects of processing, especially of blanching and canning, on the distribution of soluble and insoluble fibre and on texture and microscopic structure of carrots, the physiological effects of these raw or different processed carrots were very similar.

At first sight this finding appears to differentiate root vegetables from cereal fibre sources for which variable physiological effects have been attributed to processing. However, processing effects with cereals have mostly been studied after mechanical or heat treatments at low moisture contents or could in part be explained by formation of resistant starch. In addition, cereal fibres are normally less fermented than vegetable fibres (Wisker et al. 1988; Wisker \& Feldheim, 1990) allowing probably a larger effect of processing to be seen than with highly fermentable fibre sources.

Finally, our combined findings from the two studies make it unlikely that carrots can exert a direct fibre-mediated cholesterol-lowering effect.

We gratefully acknowledge the excellent technical assistance of Elwira Klima, Gudrun Peschutter, Silvia Reimann, Astrid Resenhoeft and Antje Richardsen. The carrots were kindly provided by Nordreco AB, Bjuv, Sweden. We thank Karl-Erik Pålsson for processing and timely delivery of all carrot samples. Gerhard Rave, University of Kiel, is gratefully acknowledged for statistical advice, and Karl-Heinz Südekum, University of Kiel, for his help with the calculations. We also thank Hans Hagemeister and his co-workers, Department of Dairy Research, Kiel, for their help with freeze-drying. Special appreciation goes to the volunteers for their excellent cooperation.

\section{REFERENCES}

Adlercreutz, H. \& Tallqvist, G. (1959). Variations in the serum total cholesterol and hematocrit values in normal women during menstrual cycle. Scandinavian Journal of Clinical and Laboratory Investigation 11, 1-9.

Anderson, N. E. \& Clydesdale, F. M. (1980). Effect of processing on dietary fiber content of wheat bran, puréed green beans, and carrots. Journal of Food Science 45, 1533-1537.

Anderson, J. W., Gustafson, N. J., Spencer, D. B., Tietyen, J. \& Bryant, C. A. (1990). Serum lipid response of 
hypercholesterolemic men to single and divided doses of canned beans. American Journal of Clinical Nutrition 51, 1013-1019.

Arbeitsgemeinschaft Getreideforschung (1978). Standard-Methoden für Getreide, Mehl und Brot (Standard Methods for Grain, Flour and Bread). Detmold, Germany: Schäfer.

Bach Knudsen, K. E., Aman, P. \& Eggum, B. O. (1987). Nutritive value of Danish grown barley varieties. I. Carbohydrate and other major constituents. Journal of Cereal Science 6, 173-186.

Berger, M. \& Venhaus, A. (1992). Dietary fibre in the prevention and treatment of diabetes mellitus. In Dietary Fibre - A Component of Food, pp. 279-292 [T. F. Schweizer and C. A. Edwards, editors]. London: Springer.

Björck, I., Nyman, M. \& Asp, N. G. (1984). Extrusion cooking of dietary fiber - effects on dietary fiber content and on degradation in the rat intestinal tract. Cereal Chemistry 61, 174-179.

Chen, W. J., Anderson, J. W. \& Jennings, D. (1984). Propionate may mediate the hypocholesterolemic effects of certain soluble plant fibres in cholesterol-fed rats. Proceedings of the Society for Experimental Biology and Medicine 175, 215-218.

Cummings, J. H. (1984). Microbial digestion of complex carbohydrates in man. Proceedings of the Nutrition Society $43,35-44$.

Cummings, J. H. (1986). The effect of dietary fiber on fecal weight and composition. In Handbook of Dietary Fiber in Human Nutrition, pp. 211-280 [G. A. Spiller, editor]. Boca Raton: CRC Press.

Demacker, P. N. M., Schade, R. W. B., Stalenhoef, A. F. H., Stuyt, P. M. J. \& Van't Laar, A. (1982). Influence of contraceptive pill and menstrual cycle on serum lipids and high-density lipoprotein cholesterol concentrations. British Medical Journal 284, 1213-1215.

Deutsche Forschungsanstalt für Lebensmittelchemie (1986). Souci, Fachmann, Kraut. Nährwert Tabellen 1986/87 (Nutrition Tables 1986/87). Stuttgart, Germany: Wissenschaftliche Verlagsgesellschaft.

Deutsche Gesellschaft für Ernährung (1988). Ernährungsbericht 1988 (Nutrition Report 1988). Frankfurt, Germany: Henrich.

Eckel, W., Wieland, H., Heuck, C. C., Seidel, D., Dietrich, R. \& Scheurler, H. (1977). Eine zuverlässige und einfache Methode zur Erkennung gefährlicher Formen von Dyslipoproteinämie (A reliable and simple procedure for detection of dangerous forms of dyslipoproteinemia). Arztliches Laboratorium 23, $101-110$.

Englyst, H. N. \& Cummings, J. H. (1984). Simplified method for the measurement of total non-starch polysaccharides by gas-liquid chromatography of constituent sugars as alditol acetates. Analyst 109, 937-942.

Gormley, T. R., Kevany, J., Egan, J. P. \& McFarlane, R. (1977). Effects of apples on serum cholesterol levels in humans. Irish Journal of Food Science and Technology 1, 117-128.

Gormley, T. R., Kevany, J., O'Donnell, B. \& McFarlane, R. (1979). Effects of peas on serum cholesterol levels in humans. Irish Journal of Food Science and Technology 3, 101-109.

Jacobs, L. R. (1990). Influence of soluble fibers on experimental colon carcinogenesis. In Dietary Fiber. Chemistry, Physiology and Health Effects, pp. 399-402. [D. Kritchevsky, C. Bonfield and J. W. Anderson, editors]. New York: Plenum Press.

Jenkins, D. J. A., Reynolds, D., Leeds, A. R., Waller, A. L. \& Cummings, J. H. (1979). Hypocholesterolemic action of dietary fiber unrelated to fecal bulking effect. American Journal of Clinical Nutrition 32, 2430-2435.

Kesäniemi, Y. A., Tarpila, S. \& Miettinen, T. A. (1990). Low vs high dietary fiber and serum, biliary, and fecal lipids in middle aged men. American Journal of Clinical Nutrition 51, 1007-1012.

Key, F. B. \& Mathers, J. C. (1990). Estimation of the digestibility of NSP for wholemeal bread and haricot beans fed in mixed diets. In Dietary Fibre, Chemical and Biological Aspects, pp. 254-258. [D. A. T. Southgate, K. Waldron, I. T. Johnson and G. R. Fenwick, editors]. Cambridge : Royal Society of Chemistry.

Kritchevsky, D. \& Story, J. A. (1986). Influence of dietary fiber on cholesterol metabolism in experimental animals. In Handbook of Dietary Fiber in Human Nutrition, pp. 129-142 [G. A. Spiller, editor]. Boca Raton: CRC Press.

Lintas, C. \& Cappeloni, M. (1988). Content and composition of dietary fibre in raw and cooked vegetables. Human Nutrition: Food Sciences and Nutrition 42F, 117-124.

Longland, A. C. \& Low, A. G. (1990). The contribution of microbial non-starch polysaccharides (NSP) to the total NSP content of faeces. In Dietary Fibre, Chemical and Biological Aspects, pp. 73-76. [D. A. T. Southgate, K. Waldron, I. T. Johnson and G. R. Fenwick, editors]. Cambridge: Royal Society of Chemistry.

McNeill, N. I. (1984). The contribution of the large intestine to energy supplies in man. American Journal of Clinical Nutrition 39, 338-342.

Nyman, M. \& Asp, N. G. (1985). Dietary fibre fermentation in the rat intestinal tract: effect of adaptation period, protein and fibre levels, and particle size. British Journal of Nutrition 54, 635-643.

Nyman, M., Björck, I., Håkansson, B. \& Asp, N.-G. (1987a). Popping of whole grain wheat. Effects on dietary fiber degradation in the rat intestinal tract. Journal of Cereal Science 5, 67-72.

Nyman, M., Pålsson, K. E. \& Asp, N. G. $(1987 \mathrm{~b})$. Effects of processing of dietary fibre in vegetables. Lebensmittel-Wissenschaft und Technologie 20, 29-36.

Nyman, M., Schweizer, T. F., Pålsson, K. E. \& Asp, N. G. (1991). Effects of processing on fermentation of dietary fibre in vegetables by rats. Lebensmittel-Wissenschaft und Technologie 24, 433-441.

Prosky, L., Asp, N.-G., Furda, I., DeVries, J. H., Schweizer, T. F. \& Harland, B. (1985). Determination of total dietary fiber in foods and food products. Collaborative study. Journal of the Association of Official Analytical Chemists 68, 677-679. 
Prosky, L., Asp, N. G., Schweizer, T. F., DeVries, J. H. \& Furda, I. (1988). Determination of insoluble, soluble, and total dietary fiber in foods and food products. Interlaboratory study. Journal of the Association of Official Analytical Chemists 71, 1017-1023.

Robertson, J., Brydon, W. G., Tadesse, K., Wenhem, P., Walls, A. \& Eastwood, M. A. (1979). The effect of raw carrot on serum lipids and colonic function. American Journal of Clinical Nutrition 32, 1889-1892.

Roediger, W. E. W. (1980). Role of anaerobic bacteria in the metabolic welfare of the colonic mucosa in man. Gut 21, 793-798.

Salyers, A. A. \& McCarthy, R. E. (1989). Assessing the importance of host-derived polysaccharides as carbon sources for bacteria growing in the human colon. Animal Feed Science and Technology 23, $109-120$.

Schweizer, T. F., Bekhechi, A. R., Koellreuter, B., Reimann, S., Pometta, D. \& Bron, B. (1983). Metabolic effects of dietary fiber from dehulled soybeans in humans. American Journal of Clinical Nutrition 38, 1-11.

Stasse-Wolthuis, M., Albers, H. F. F., VanJeveren, J. G. C., DeJong, J. W., Hautvast, J. G. A. J., Hermus, R. J. J., Katan, M. B., Brydon, W. G. \& Eastwood, M. A. (1980). Influence of dietary fiber from vegetables and fruits, bran or citrus pectin on serum lipids, fecal lipids, and colonic function. American Journal of Clinical Nutrition 33, 1745-1756.

Stasse-Wolthuis, M., Hautvast, J. G. A. J., Hermus, R. J. J., Katan, M. B., Bausch, J. E., Rietberg-Brussaard, J. H., Velema, J. P., Zondervan, J. H., Eastwood, M. A. \& Brydon, W. G. (1979). The effect of a natural high fiber diet on serum lipids, fecal lipids, and colonic function. American Journal of Clinical Nutrition 32 , 1881-1888.

Stephen, A. M. \& Cummings, J. H. (1980a). Mechanism of action of dietary fibre in the human colon. Nature 284, $283-284$

Stephen, A. M. \& Cummings, J. H. (1980 b). The microbial contribution to human faecal mass. Journal of Medical Microbiology 13, 46-56.

Theander, O. \& Westerlund, E. A. (1986). Studies on dietary fiber. 3. Improved procedure for analysis of dietary fiber. Journal of Agricultural and Food Chemistry 34, 330-336.

Truswell, A. S. \& Beynen, A. C. (1992). Dietary fiber and plasma lipids: potential for prevention and treatment of hyperlipidaemias. In Dietary Fibre - A Component of Food, pp. 295-332 [T. F. Schweizer and C. A. Edwards, editors]. London: Sprin ter.

Wisker, E. \& Feldheim, V . (1990). Metabolizable energy from diets high or low in dietary fiber from fruits and vegetables when consur_ed by humans. Journal of Nutrition 120, 1331-1337.

Wisker, E., Godau, A., Daniel, M., Peschutter, G. \& Feldheim, W. (1992). Contribution of barley fiber to the metabolizable energy of human diets. Nutrition Research 12, 1315-1323.

Wisker, E., Krumm, U. \& Feldheim, W. (1986). Einfluß der Partikelgröße von Getreideprodukten auf das Stuhlgewicht von jungen Frauen (Influence of particle size of cereals on stool weight in young women). Aktuelle Ernährung 11, 208-211.

Wisker, E., Maltz, A. \& Feldheim, W. (1988). Metabolizable energy of diets low or high in dietary fiber from cereals when eaten by humans. Journal of Nutrition 118, 945-952.

Wyman, J. B., Heaton, K. W., Manning, A. P. \& Wicks, A. C. B. (1976). The effect on intestinal transit and the feces of raw and cooked bran in different doses. American Journal of Clinical Nutrition 29, 1474-1479. 